\title{
Effects of combined fungicide in stingless bees Scaptotrigona bipunctata
}

\author{
Efeitos de fungicida combinado em abellhas sem ferrão Scaptotrigona bipunctata \\ Efectos del fungicida combinado en abejas sin aguijón Scaptotrigona bipunctata
}

Received: 01/16/2021 | Reviewed: 01/21/2021 | Accept: 01/23/2021 | Published: 01/30/2021

\author{
Tamiris de Oliveira Diniz \\ ORCID: https://orcid.org/0000-0002-9737-9154 \\ Universidade Estadual de Maringá, Brazil \\ E-mail: tamirisc.biologicas@hotmail.com \\ Naiara Climas Pereira \\ ORCID: https://orcid.org/0000-0003-1718-0848 \\ Universidade Estadual de Maringá, Brazil \\ E-mail: naiaraclimas@gmail.com \\ Breno Gabriel da Silva \\ ORCID: https://orcid.org/0000-0002-8322-9235 \\ Universidade de São Paulo, Brazil \\ E-mail: brenogsilva@usp.br \\ William Cristian da Silva Pizzaia \\ ORCID: https://orcid.org/0000-0002-5160-2883 \\ Universidade Estadual de Maringá, Brazil \\ E-mail: wilbiologia@hotmail.com \\ Fernanda Giovana Martins de Oliveira \\ ORCID: https://orcid.org/0000-0003-1401-4334 \\ Universidade Estadual de Maringá, Brazil \\ E-mail: fer_giovana@hotmail.com \\ Adriana Aparecida Sinópolis-Gigliolli \\ ORCID: https://orcid.org/0000-0002-2752-642X \\ Universidade Estadual de Maringá, Brazil \\ E-mail: adrianasinopolis@ hotmail.com \\ Vagner de Alencar Arnaut de Toledo \\ ORCID: https://orcid.org/0000-0003-1814-9703 \\ Universidade Estadual de Maringá, Brazil \\ E-mail: vaatoledo1975@gmail.com \\ Maria Claudia Colla Ruvolo-Takasusuki \\ ORCID: https://orcid.org/0000-0002-2028-9281 \\ Universidade Estadual de Maringá, Brazil \\ E-mail: claudia.ruvolo@gmail.com
}

\begin{abstract}
Locker is a fungicide used in different crops for biological control, affecting both insect pests and pollinators, such as bees. This study aimed to evaluate toxicity and establish the lethal concentration $\left(\mathrm{LC}_{50}\right)$ of the fungicide Locker in stingless bees Scaptotrigona bipunctata, investigating changes in brain cells chromatin structure and in midgut morphology. This agrochemical is a combined fungicide that contains three active ingredients: benzimidazole, triazole and strobilurin. Adult forage bees were orally exposed to the following concentrations: $1.7 \mathrm{mg}$ a.i./L; $2.55 \mathrm{mg}$ a.i./L; $3.4 \mathrm{mg}$ a.i./L and $4.25 \mathrm{mg}$ a.i./L of fungicide, and submitted to histochemical and morphological analysis 24,48 and 72 hours after ingestion. The analysis of $S$. bipunctata brain cells showed changes in chromatin condensation in all treatments. There were also several morphological changes in the midgut at all concentrations and exposure times. Thus, the fungicide Locker significantly affected bee survival, inducing changes in their internal morphology, which can lead to alterations in their activities, directly interfering in their foraging behavior and survival.

Keywords: Histology; Scanning electron microscopy; Critical electrolyte concentration; Benzimidazole; Triazole; Strobilurin.
\end{abstract}

\section{Resumo}

Locker é um fungicida utilizado em diferentes culturas para controle biológico, afetando tanto insetos pragas quanto polinizadores, como as abelhas. Este estudo teve como objetivo avaliar a toxicidade e estabelecer a concentração letal $\left(\mathrm{CL}_{50}\right)$ do fungicida Locker em abelhas sem ferrão Scaptotrigona bipunctata, investigando alterações na estrutura da cromatina das células cerebrais e na morfologia do intestino médio das abelhas. O produto utilizado é um fungicida combinado que contém três ingredientes ativos: benzimidazol, triazol e estrobilurina. Abelhas forrageiras adultas foram expostas via oral às concentrações de $1,7 \mathrm{mg}$ i.a./L; $2,55 \mathrm{mg}$ a.i./L; 3,4 mg i.a./L e 4,25 mg i.a./L de fungicida, e submetidas à análises histoquímicas e morfológicas após 24, 48 e 72 horas da ingestão do produto. A análise das 
células cerebrais de $S$. bipunctata mostrou alterações na condensação da cromatina em todos os tratamentos. Houve também várias mudanças morfológicas no intestino médio em todas as concentrações e tempos de exposição. Dessa forma, o fungicida Locker afetou significativamente a sobrevivência das abelhas, induzindo alterações em sua morfologia interna, que podem levar a alterações em suas atividades, interferindo diretamente em seu comportamento de forrageamento e sobrevivência.

Palavras-chave: Histologia; Microscopia eletrônica de varredura; Concentração crítica de eletrólitos; Benzimidazol; Triazol; Estrobirulina.

\section{Resumen}

Locker es un fungicida utilizado en diferentes cultivos para el control biológico, que afecta tanto a insectos plagas como a polinizadores, como las abejas. Este estudio tuvo como objetivo evaluar la toxicidad y establecer la concentración letal $\left(\mathrm{CL}_{50}\right)$ del fungicida Locker en abejas sin aguijón Scaptotrigona bipunctata, investigando cambios en la estructura de la cromatina de las células cerebrales y en la morfología del intestino de la abeja. El producto utilizado es un fungicida combinado que contiene tres principios activos: benzimidazol, triazol y estrobilurina. Las abejas forrajeras adultas fueron expuestas por vía oral a concentraciones de 1,7 mg a.i./L; 2,55 mg a.i./L; 3,4 mg a.i./L y 4,25 mg a.i./L de fungicida, y sometidos a análisis histoquímico y morfológico 24, 48 y 72 horas después de la ingestión del producto. El análisis de células cerebrales de S. bipunctata mostró cambios en la condensación de cromatina en todos los tratamientos. También hubo varios cambios morfológicos en el intestino medio en todas las concentraciones y tiempos de exposición. Así, el fungicida Locker afectó significativamente la supervivencia de las abejas, induciendo cambios en su morfología interna, lo que puede conducir a cambios en sus actividades, interfiriendo directamente en su comportamiento de forrajeo y supervivencia.

Palabras clave: Histología; Microscopía electrónica de barrido; Concentración crítica de electrolitos; Bencimidazol; Triazol; Estrobirulina.

\section{Introduction}

Scaptotrigona bipunctata (Lepeletier) (Hymenoptera: Apidae) is a stingless bee found in several Brazilian states, such as Acre, Ceará, Maranhão, Minas Gerais, Paraná, Pará, Rio Grande do Sul, Rio de Janeiro and Santa Catarina (Camargo \& Pedro, 1836). Despite having very populous colonies and great potential as pollinating insects, studies on their susceptibility to agrochemicals are rare (Diniz et al., 2020).

Anthropic activities such as agriculture, deforestation and urban development have threatened biodiversity (Barbosa et al., 2017) and directly affected pollinating species. In this context, the unsustainable use of agricultural ecosystems and the excessive application of agrichemicals have been considered the major causes of bee diversity losses (Sanchez-Bayo \& Goka, 2014). Thus, the use of agrochemicals in crops that produce flowers attractive to bees should be considered in risk studies for pollinating species (Imperatriz-Fonseca, 2004).

The fungicide Locker acts as a systemic and contact agrochemical and contains three chemical groups: benzimidazole, triazole and strobilurin. Carbendazim is the most widely used active ingredient among the benzimidazole fungicides and it is persistence in the environment (Coutinho et al., 2006). On the other hand, triazole impairs the synthesis of ergosterol (SuethSantiago et al., 2015) which is a steroid found in the fungal cell membrane (Sidrim \& Rocha, 2012). Strobilurin performs different biological activities, inhibiting mitochondrial respiration by blocking electron transfer between cytochromes B and C, which interferes with ATP generation (Zauza et al., 2008).

It is essential to measure the effectiveness of agrochemicals used in crops on target and non-target insects, such as bees. Changes in chromatin integrity can be used to identify the presence of external agents (Santos et al., 2014). Morphophysiological analyses help to analyze exposure to agrochemicals (Tavares et al., 2015) because it is in the midgut of bees that most of the metabolism occurs (Diniz et al., 2020).

Stingless bees are more sensitive to agrochemicals than other bee species, so the use of these compounds in agriculture has threatened the survival of colonies, which in many cases are near crops, making it critical to evaluate the toxicity of these agrochemicals to ensure bee protection (Arena \& Sgolastra, 2014). Thus, this study aimed to assess the toxicity and establish the lethal concentration $\left(\mathrm{LC}_{50}\right)$ of the fungicide Locker in S. bipunctata, investigating changes in the 
chromatin structure of brain cells and midgut morphology.

\section{Material and Methods}

This quantitative research is characterized by the use of quantification, both in the collection as in the treatment of information, using statistical techniques (Richardson, 1999).

\section{Biological material}

Adult S. bipunctata forager workers were collected at the entrance of the colony, when they returned from foraging, in the meliponary of the Fazenda Experimental de Iguatemi (FEI) $\left(23^{\circ} 25^{\prime} \mathrm{S}\right.$ and $\left.51^{\circ} 57^{\prime} \mathrm{O}\right)$, from Universidade Estadual de Maringá and taken to the Animal Genetics Laboratory of the Department of Biotechnology, Genetics and Cell Biology of the Universidade Estadual de Maringá.

\section{Bioassays}

The agrochemical used is called Locker and is a ready-made mixture of systemic and contact fungicides from three groups Benzimidazole (200 g/L), Triazole (100 g/L) and Strobilurin (125 g/L) (Adapar, 2019). Preliminary tests were performed to determine the concentrations to be used $(1.7 \mathrm{mg}$ a.i./L; $2.55 \mathrm{mg}$ a.i./L; $3.4 \mathrm{mg}$ a.i./L and $4.25 \mathrm{mg}$ a.i./L). The concentrations tested were evaluated by the ingestion test and added to the syrup which consisted of a mixture of water and sugar.

The bioassays were performed in quadruplicate, with 15 adult S. bipunctata workers per concentration, totaling 60 individuals for each concentration and the control group. In each bioassay, 300 individuals were evaluated, and each experiment was established to evaluate the methods analyzed. To replicate and control the groups, glass bottles containing filter paper, cotton soaked in water and a container containing syrup with one of the fungicide concentrations were used.

The control conditions were the same as those used for the treatments, but only syrup was provided as food. The vials were kept at $28 \pm 2^{\circ} \mathrm{C}$, RH $70 \% \pm 10 \%$ for $72 \mathrm{~h}$, and the different evaluations were performed. After 24,48 and $72 \mathrm{~h}$, the lethal concentration for $50 \%$ of the exposed insects $\left(\mathrm{LC}_{50}\right)$ was determined based on mortality.

\section{Changes in chromatin}

To investigate possible changes in the brain chromatin structure, the protocol described by Vidal and Mello (1989) was used. The brains of surviving bees were dissected after 24,48 and $72 \mathrm{~h}$ of insecticide intake, placed in saline solution for insects $\left(\mathrm{NaCl} 0.1 \mathrm{M}, \mathrm{Na}_{2} \mathrm{HPO}_{4} 0.1 \mathrm{M}\right.$ and $\mathrm{KH}_{2} \mathrm{PO}_{4} 0.1 \mathrm{M}$ ), extended in microscopy slides, with acetic acid (45\%) and crushed under a glass slide. Microscopy slides were frozen in liquid nitrogen and the glass slide removed when it reached room temperature. The material was fixed in ethanol:acetic (3:1 v/v) acid for $1 \mathrm{~min}$ and the slide was washed in ethanol for $5 \mathrm{~min}$.

For each treatment, nine slides were used, totaling 135 slides analyzed. These were stained for 20 min with TB $0.025 \%$ in a Mcllvaine buffer ( $\mathrm{pH} 4.0)$, contained different $\mathrm{MgCl}_{2}$ concentrations $(0.0 ; 0.02 ; 0.05 ; 0.08 ; 0.10 ; 0.12 ; 0.15 ; 0.20$; and $0.30 \mathrm{~mol} / \mathrm{L}$ ). Then, slides were washed in distilled water and air-dried, bleached in Xylol for $15 \mathrm{~min}$, assembled in Entellan, analyzed and photographed under a Zeiss standard optical microscopy. The cell nuclei stained violet were the controls and the green color corresponding to the CEC point.

\section{Midgut alterations}

Scanning electron microscopy (SEM) and light microscopy were used to verify possible changes in the midgut of bees contaminated with the fungicide. 
For SEM, surviving bees were anesthetized under cold temperatures and the midgut was dissected in a physiological solution for insects, then fixed in aqueous Bouin's solution (picric acid, formaldehyde and acetic acid) for $12 \mathrm{~h}$, being dehydrated in an alcohol series of increasing concentrations $(70 \%, 80 \%, 90 \%$ and $100 \%)$. Samples were submitted to a criticalpoint dry (Leica CPD 030) and covered by gold dust on the metallizer Shimadzu IC-50. Analyses were performed using the MEV QUANTA 250 of the Microscopy Center of the Complex of Research Support Centre (COMCAP) of the Universidade Estadual de Maringá/Paraná/Brazil.

After exposure to the fungicide Locker at the previously mentioned concentrations, for a period of 24,48 and $72 \mathrm{~h}$, the surviving individuals were anesthetized under cold temperatures and the midgut were dissected in saline solution for insects. Samples were fixed in aqueous Bouin's solution for $12 \mathrm{~h}$, dehydrated in an alcohol series of increasing concentrations, diaphanized in xylene (100\%), paraffin-embedded and sectioned into $6 \mu \mathrm{m}$ slices using a microtome Leica RM 2250. Then, sections were spread on glass slides, rehydrated, and stained with Hematoxylin and eosin (H/E). The analyses were performed under an Olympus light microscope and sections were photographed using a digital camera.

\section{Data analysis}

The Shapiro-Wilk test was used to investigate the assumption of normality of the mortality variable. The KruskalWallis test was used to verify whether there were median differences in working-class mortality according to the concentration level. To verify the ideal concentration of the fungicide the binary regression model with probit binding function was used. For the diagnostic analysis of the model, the normal probability graph with simulated envelope was used and for the adjustment, quality deviance was used. The significance level was $5 \%$ and the statistical analyses were performed at the R software version 4.0.2 (R Core Team, 2020).

\section{Results and Discussion}

\section{Toxicity}

The Shapiro-Wilk test indicated that the hypothesis of normality of bee mortality was violated in all experimental periods ( $p$-value < 0.05). Once the hypothesis of normality was not satisfied, the Kruskal-Wallis nonparametric test was applied, which showed that there were significant differences in mortality considering the concentration levels (p-value < 0.05), for all experimental periods. All assumptions for the suitability of the adjusted models in the three periods were met.

After $24 \mathrm{~h}$ of oral contamination with Locker, the mortality per concentration gradually increased. After $48 \mathrm{~h}$, the mortality was higher in the highest concentration (4.25 mg a.i./L). After $72 \mathrm{~h}$, the mortality variability was higher at the concentrations $2.55 \mathrm{mg}$ a.i./L and $4.25 \mathrm{mg}$ a.i./L (Figure 1). 
Figure 1. Boxplot of S. bipunctata mortality orally contaminated with the fungicide Locker after (a) 24 , (b) 48 and (c) 72 hours.
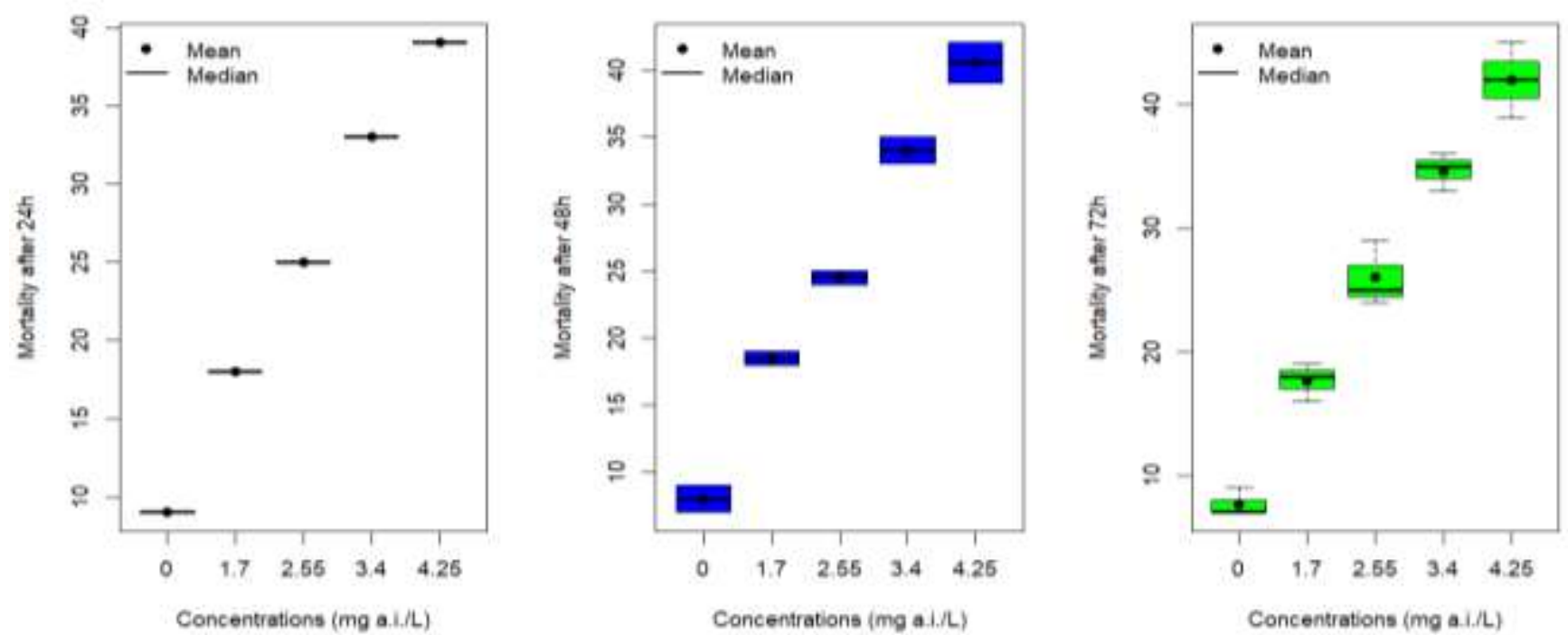

Source: Authors.

When the response variable is defined as the total dichotomous values in $\mathrm{n}$ sample observations, the binary regression technique, such as the binomial model, is recommended. Therefore, to estimate the lethal concentration $\left(\mathrm{LC}_{50}\right)$ these models were adjusted. Thus, after applying the exponential to the results obtained on a logarithmic scale, the results obtained for $\mathrm{LC}_{50}$ were: $3.06 \mathrm{mg}$ a.i./L, for $24 \mathrm{~h}, 2.63 \mathrm{mg}$ a.i./L, for $48 \mathrm{~h}$ and $7.31 \mathrm{mg}$ a.i./L for $72 \mathrm{~h}$ (Figure 2).

Although fungicides are widely used in agriculture, studies analysing the effects of this group of agrochemicals on stingless bees are still scarce, and many gaps limit the understanding of bee responses to their exposure. The fungicide used in this study is a combination of products of different chemical classes and there is still no estimated $\mathrm{LC}_{50}$ for bees or insects in general, nor studies on the effects of this product and its compounds on these organisms.

Figure 2. Lethal concentration curve of S. bipunctata mortality after oral contamination with Locker fungicide.

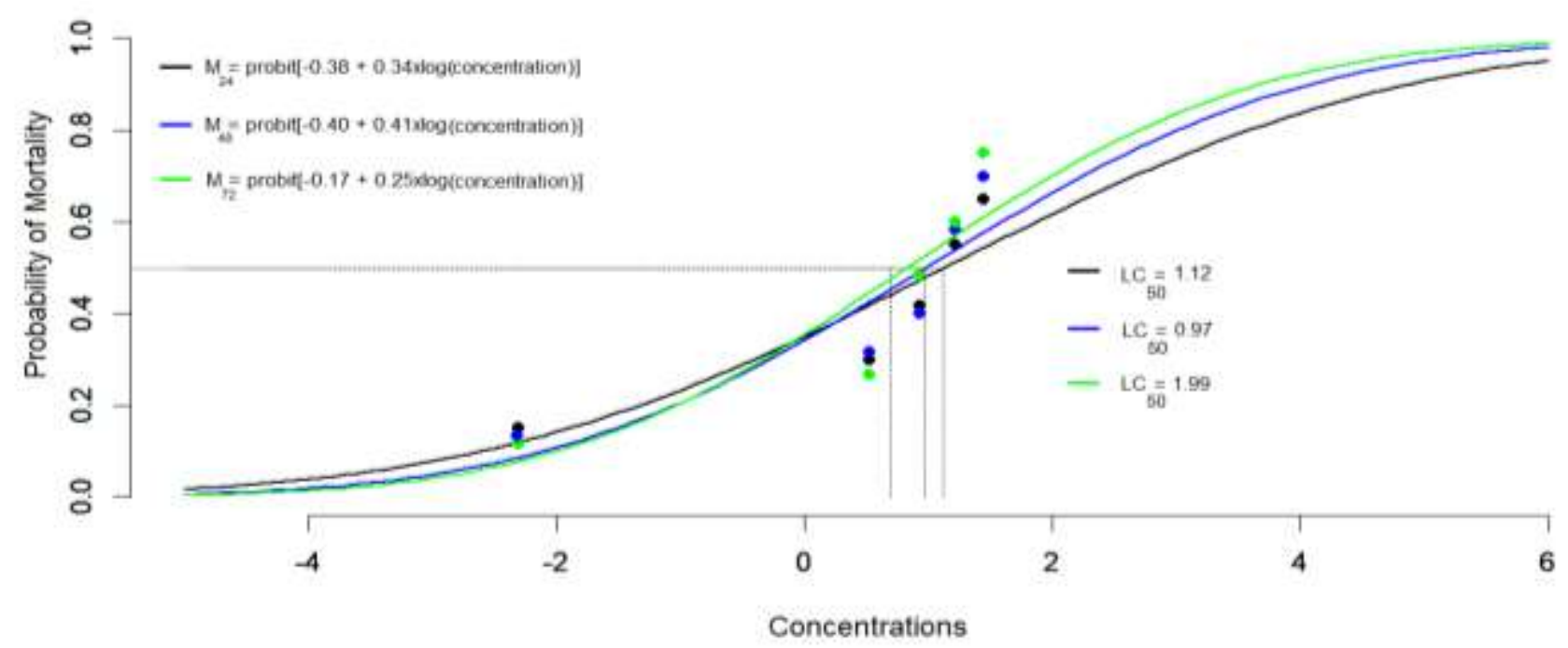

Source: Authors. 
According to the IPCS (2006), carbendazim, the main Locker compound, is nontoxic to bees, however, the results obtained in this study may indicate the opposite, due to the observed mortality. Furthermore, additional studies on the effects of this product on non-target organisms are needed, since after its application in crops several species are exposed to this agrochemical.

Domingues et al. (2020) investigated the effects of residual concentrations of the fungicide pyraclostrobin (strobilurin) on Apis mellifera and found that the survival rate of honeybees contaminated with fungicide was affected, especially in older workers.

The fungicide activity of strobilurin occurs due to its ability to inhibit mitochondrial respiration by binding at site Q0 (quinone oxidase) of cytochrome b, located in the inner membrane of the fungi mitochondria and other eukaryotes (Bartlett et al., 2002). In non-target organisms, such as insects, the fungicide can affect the mitochondrial bioenergetic system (Nicodemo et al., 2018), and inhibit in vitro mitochondria oxidation isolated from A. mellifera (Campbell et al., 2016).

\section{Cytochemical analysis of brain cells}

After oral contamination of S. bipunctata with the fungicide Locker, chromatin condensation was observed only at the highest concentration ( $4.25 \mathrm{mg}$ a.i./L) (Figure $3 \mathrm{a}$ ). After $48 \mathrm{~h}$ of contamination, the bees from the treatment of $2.55 \mathrm{mg}$ a.i./L showed CEC point at $0.30 \mathrm{M}$, while the bees from the treatment of $4.25 \mathrm{mg}$ a.i./L had CEC point at $0.20 \mathrm{M}$, similar to the control group (Figure $3 \mathrm{~b}$ ). Finally, after $72 \mathrm{~h}$ the treatments of $1.7 \mathrm{mg}$ a.i./L, $2.55 \mathrm{mg}$ a.i./L and $3.4 \mathrm{mg}$ a.i./L had CEC point at $0.30 \mathrm{M}$, while only the treatment of $4.25 \mathrm{mg}$ a.i./L had a CEC point similar to the control group (Figure $3 \mathrm{c}$ ).

The analysis of the critical concentration of electrolytes showed that changes occurred in the chromatin structure of $S$. bipunctata brain cells after contamination with the fungicide Locker. There are no studies yet of nuclear basophilia reporting the effects of this chemical class of fungicide on bees or other insects.

Changes in chromatin integrity are a useful tool to identify the presence of external agents in the body (Santos et al., 2014). Thus, nuclear basophilia can be established and used to estimate the levels of DNA-protein complexation in the chromatin, using the cationic dye Toluidine Blue (TB) (Vidal, 1987). Therefore, if TB staining occurs in the presence of $\mathrm{Mg}_{2}{ }^{+}$ ions, the dispute over phosphate groups available from DNA and RNA in the sample also begins.

Depending on the concentration of $\mathrm{Mg}_{2}{ }^{+}$that binds to DNA, the metachromasia stop and the sample is greenish stained. This concentration varies according to the chromatin condensation when higher values are obtained in more condensed chromatin (Vidal \& Mello, 1989). Changes in chromatin structure influence gene expression, when the chromatin is condensed (heterochromatin) genes are inactive, but when there is euchromatin there is gene expression (Rodenhiser \& Mann, 2006).

In addition to the lethal effects, agrochemicals can cause sublethal effects and induce behavioral changes in insects (Rossi et al., 2013), such as compromise foraging, navigation performance and social communication (Tison et al., 2016); reduce proboscis retraction, impairing feeding (Thany et al., 2015) and also decrease the ability of bees to return to the colony (Freitas \& Pinheiro, 2010). 
Figure 3. Nuclear basophilia of S. bipunctata brain after (a) 24, (b) 48 and (c) 72 h of oral exposure to the fungicide Locker [stained with $0.025 \%$ toluidine blue (TB) added of $\mathrm{MgCl}_{2}$ in various concentrations (mol/L)]

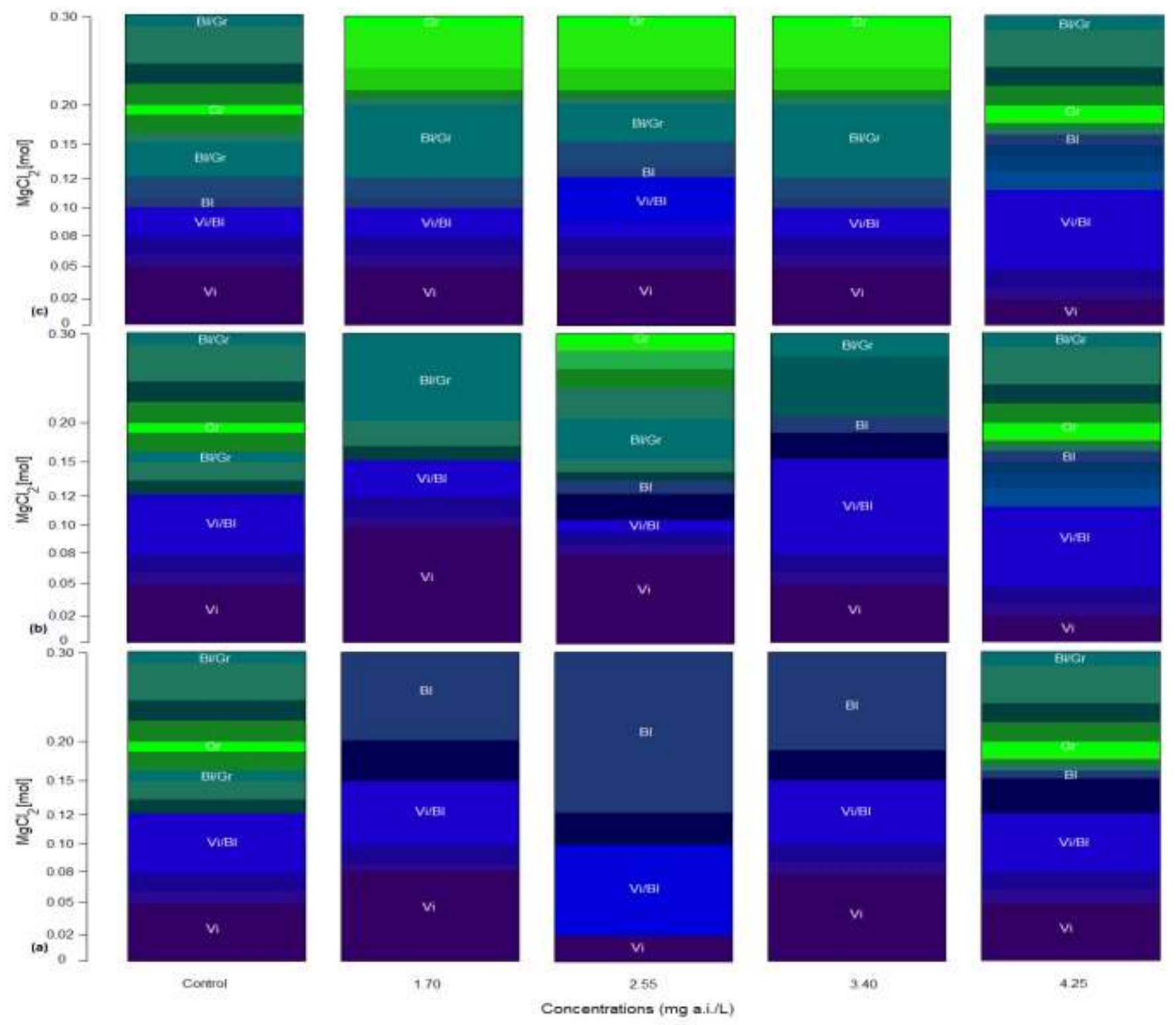

Bl, blue; Gr, green; Vi: violet. Source: Authors.

\section{Midgut morphological analysis}

After $24 \mathrm{~h}$ of $S$. bipunctata contamination with the fungicide Locker, the longitudinal musculature was loose and the longitudinal muscle fibers were thin in all treatments (Figure 4 B - E). Slight epithelium disorganization (Figure 5 D) and loss of digestive cells (Figure $5 \mathrm{~B}-\mathrm{E}$ ) were also observed.

After $48 \mathrm{~h}$ of oral contamination, the longitudinal musculature was loosened and thin in all treatments (Figure $6 \mathrm{~B}-$ E), there was a loss of digestive cells for the lumen (Figure 7 B, D - E), musculature loosening and epithelium degradation (Figure $7 \mathrm{~B}-\mathrm{D}$ ), and remnants of the peritrophic membrane (Figure $7 \mathrm{D}-\mathrm{E}$ ).

After $72 \mathrm{~h}$ of contamination with the fungicide Locker, the longitudinal fibers of the midgut were looser and slender (Figure $8 \mathrm{~B}-\mathrm{E}$ ), there was also musculature loosening (Figure $9 \mathrm{~B}-\mathrm{D}$ ), epithelium degradation and remnants of the peritrophic membrane in all treatments (Figure $9 \mathrm{~B}-\mathrm{E}$ ). 
Research, Society and Development, v. 10, n. 1, e53710112029, 2021

(CC BY 4.0) | ISSN 2525-3409 | DOI: http://dx.doi.org/10.33448/rsd-v10i1.12029

Figure 4. Scanning electron microscopy showing the midgut of S. bipunctata after $24 \mathrm{~h}$ of ingestion of the fungicide Locker.
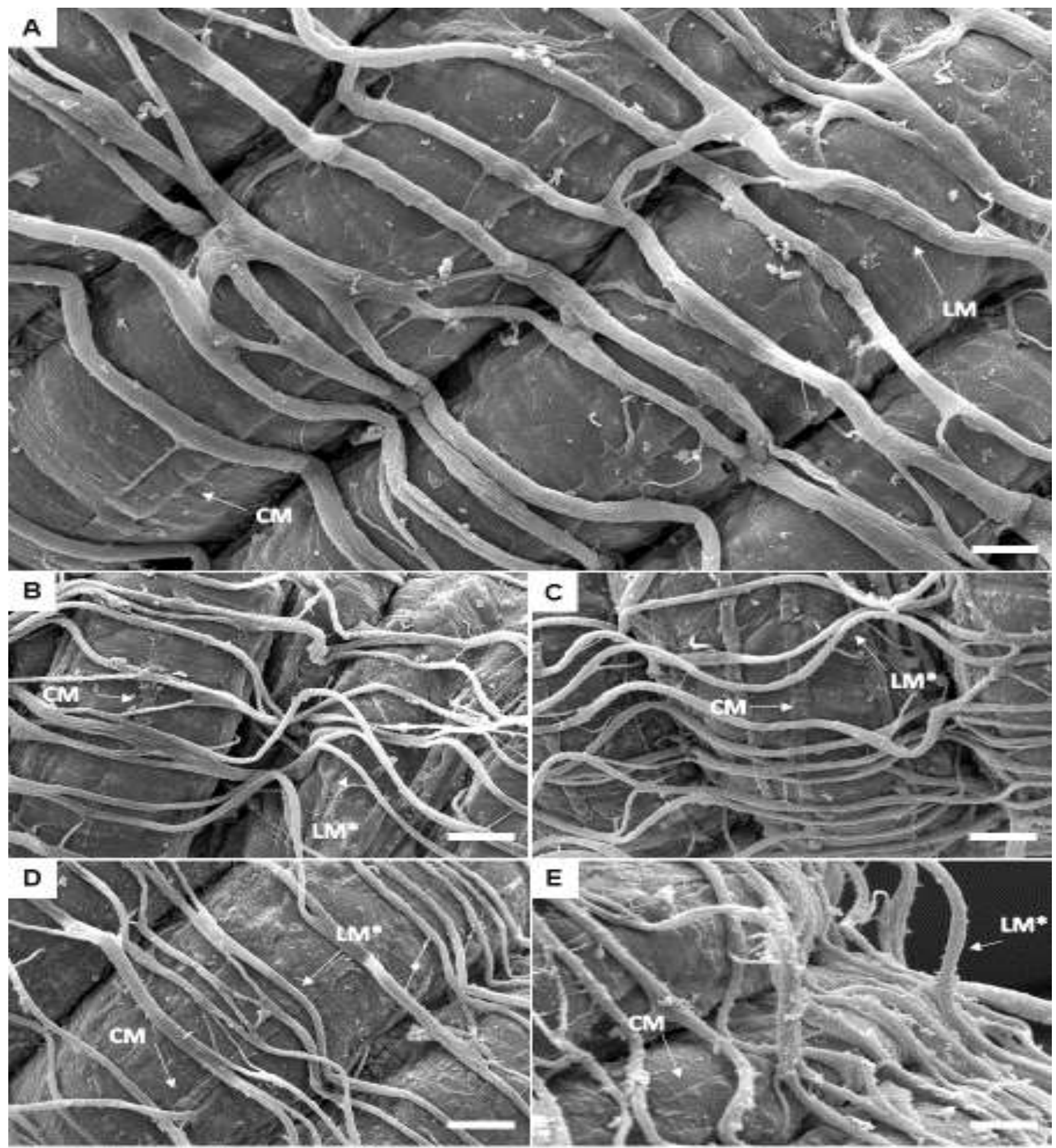

A, control; B, $1.7 \mathrm{mg}$ a.i./L; C, $2.55 \mathrm{mg}$ a.i./L; D, $3.4 \mathrm{mg}$ a.i./L; E, $4.25 \mathrm{mg}$ a.i./L. CM, Circular musculature; LM, Longitudinal musculature; LM*, Longitudinal musculature showing alterations; T, Tracheoles. Scale bar: $50 \mu \mathrm{m}$.

Source: Authors. 
Figure 5. Photomicrography showing the midgut of S. bipunctata after $24 \mathrm{~h}$ of oral contamination with the fungicide Locker.

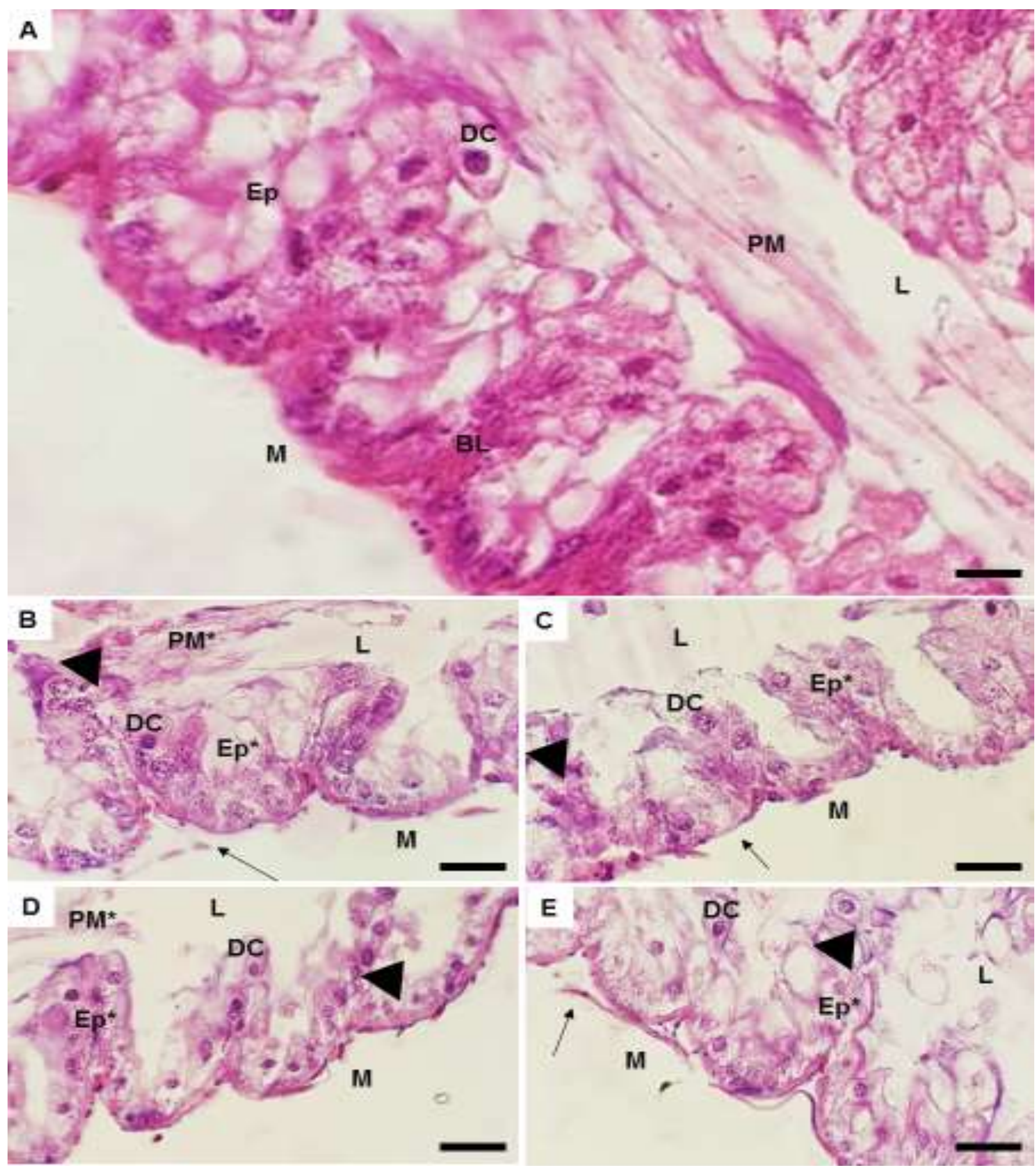

A, control; B, 1.7 mg i.a./L; C, 2.55 mg i.a./L; D, 3.4 mg i.a./L; E, 4.25 mg i.a./L. DC, Digestive cells; Ep, Epithelium; Ep*, Epithelium showing alterations; L, Lumen; BL, Basal lamina; M, Musculature; PM, Peritrophic membrane; PM*, Peritrophic membrane showing alterations; $\uparrow$, Musculature showing alterations; , Loss of digestive cells to the lumen. Hematoxylin-Eosin staining. Scale bar: $20 \mu \mathrm{m}$. Source: Authors. 
Research, Society and Development, v. 10, n. 1, e53710112029, 2021

(CC BY 4.0) | ISSN 2525-3409 | DOI: http://dx.doi.org/10.33448/rsd-v10i1.12029

Figure 6. Scanning electron microscopy showing the midgut of S. bipunctata after $48 \mathrm{~h}$ of ingestion of the fungicide Locker.
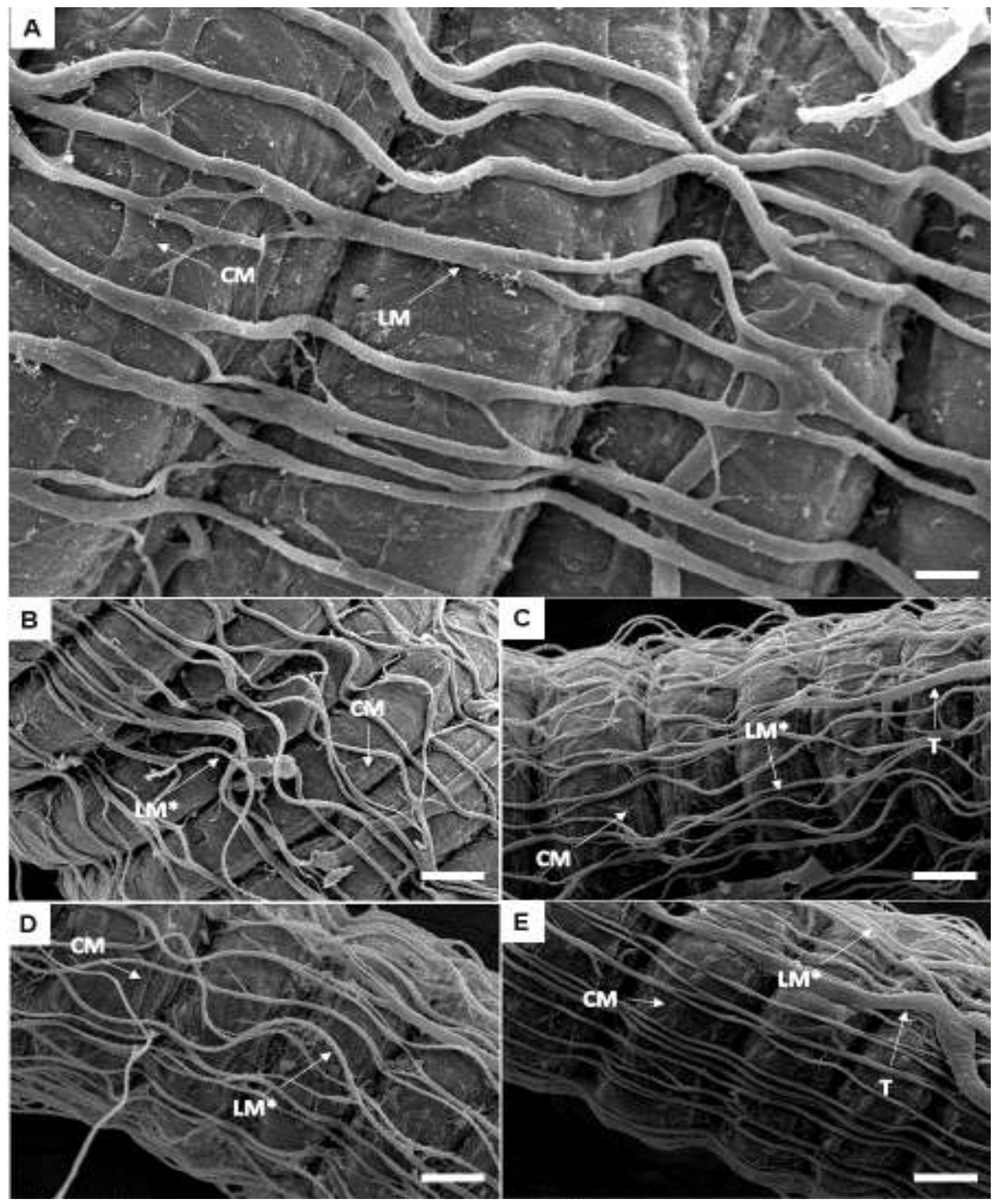

A, control; B, $1.7 \mathrm{mg}$ a.i./L; C, $2.55 \mathrm{mg}$ a.i./L; D, $3.4 \mathrm{mg}$ a.i./L; E, $4.25 \mathrm{mg}$ a.i./L. CM, Circular musculature; LM, Longitudinal musculature; $\mathrm{LM}^{*}$, Longitudinal musculature showing alterations; T, Tracheoles. Scale bar: $50 \mu \mathrm{m}$.

Source: Authors. 
Research, Society and Development, v. 10, n. 1, e53710112029, 2021

(CC BY 4.0) | ISSN 2525-3409 | DOI: http://dx.doi.org/10.33448/rsd-v10i1.12029

Figure 7. Photomicrography showing the midgut of $S$. bipunctata after $48 \mathrm{~h}$ of oral contamination with the fungicide Locker.

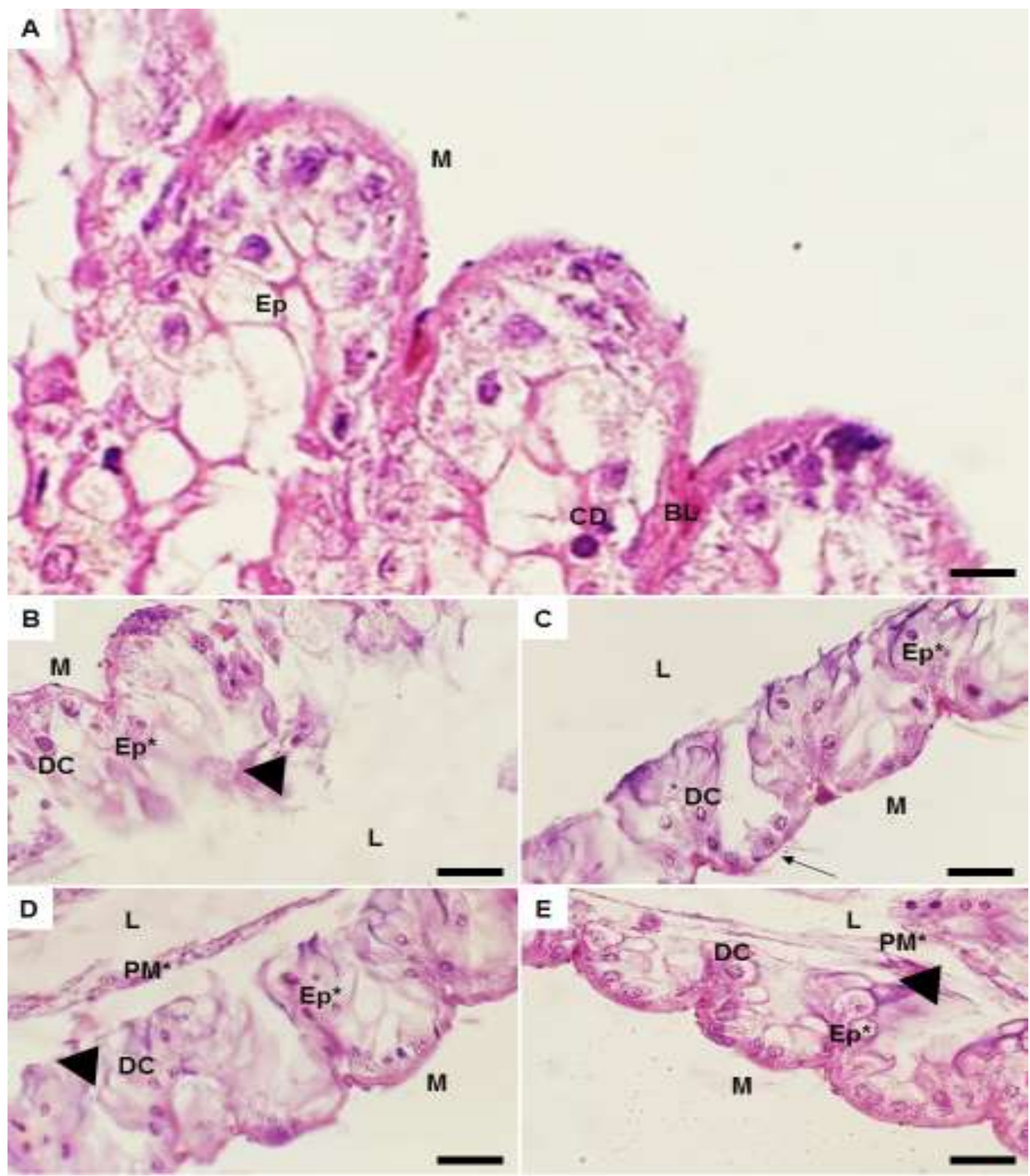

A, control; B, $1.7 \mathrm{mg}$ i.a./L; C, $2.55 \mathrm{mg}$ i.a./L; D, $3.4 \mathrm{mg}$ i.a./L; E, $4.25 \mathrm{mg}$ i.a./L. DC, Digestive cells; Ep, Epithelium; Ep*, Epithelium showing alterations; L, Lumen; BL, Basal lamina; M, Musculature; PM, Peritrophic membrane; MP*, Peritrophic membrane showing alterations; T, Musculature showing alterations; Loss of digestive cells to the lumen. Hematoxylin-Eosin staining. Scale bar: $20 \mu \mathrm{m}$. Source: Authors. 
Research, Society and Development, v. 10, n. 1, e53710112029, 2021

(CC BY 4.0) | ISSN 2525-3409 | DOI: http://dx.doi.org/10.33448/rsd-v10i1.12029

Figure 8. Scanning electron microscopy showing the midgut of S. bipunctata after $72 \mathrm{~h}$ of ingestion of the fungicide Locker.
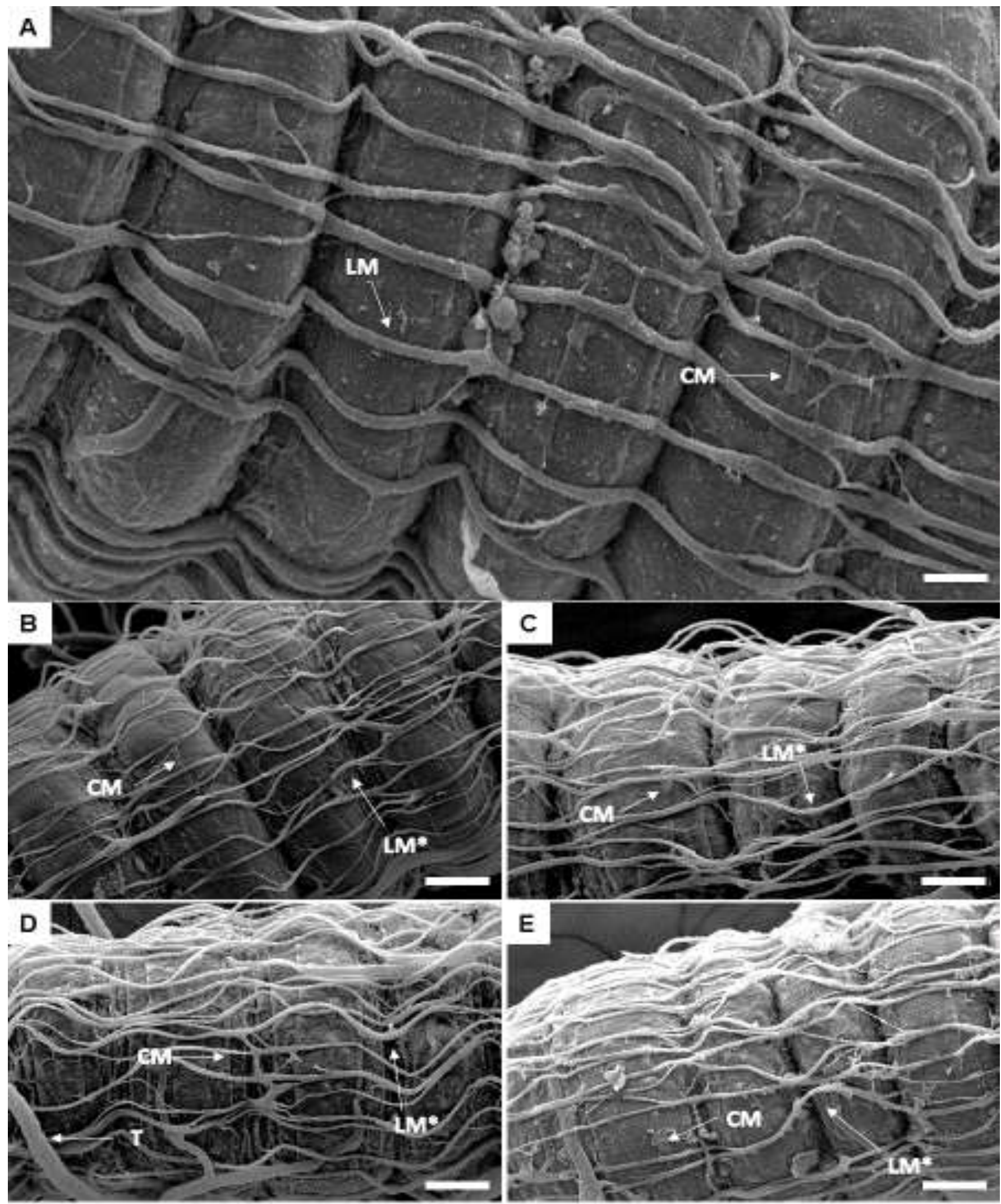

A, control; B, $1.7 \mathrm{mg}$ a.i./L; C, $2.55 \mathrm{mg}$ a.i./L; D, $3.4 \mathrm{mg}$ a.i./L; E, $4.25 \mathrm{mg}$ a.i./L. CM, Circular musculature; LM, Longitudinal musculature; $\mathrm{LM}^{*}$, Longitudinal musculature showing alterations; T, Tracheoles. Scale bar: $50 \mu \mathrm{m}$.

Source: Authors. 
Figure 9. Photomicrography showing the midgut of $S$. bipunctata after $72 \mathrm{~h}$ of oral contamination with the fungicide Locker.

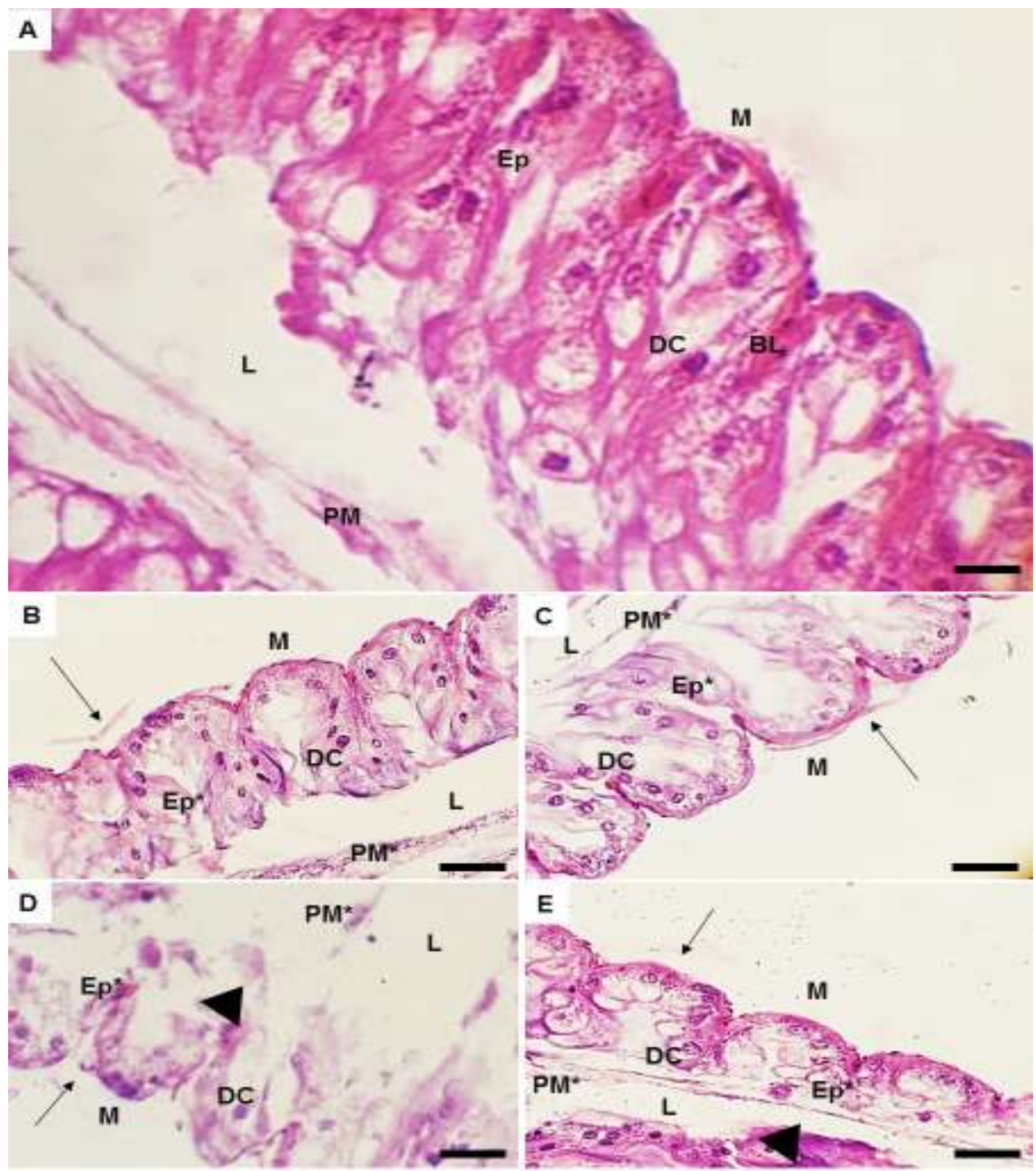

A, control; B, 1.7 mg i.a./L; C, 2.55 mg i.a./L; D, 3.4 mg i.a./L; E, 4.25 mg i.a./L. DC, Digestive cells; Ep, Epithelium; Ep*, Epithelium showing alterations; L, Lumen; BL, Basal lanina; M, Musculature; PM, Peritrophic membrane; MP*, Peritrophic membrane showing alterations; $\boldsymbol{T}$, Musculature showing alterations; , Loss of digestive cells to the lumen. Hematoxylin-Eosin staining. Scale bar: $20 \mu \mathrm{m}$. Source: Authors.

The sublethal effects of agrochemicals can be detected at the cellular level. Morphological analysis of internal organs is an important tool to evaluate cytotoxicity and/or adaptive responses to chemical stress-induced by chemical compounds in 
bees (Malaspina \& Silva-Zacarin, 2006).

Fungicides are the main agrochemicals found in pollen grains, which are the principal source of protein for bees (Carneiro et al., 2020). Although the effects of insecticides on bees are widely studied, there is growing evidence that fungicides are also not harmless to bees (Batista et al., 2020).

The midgut is the region where nutrient absorption and metabolization occur, constituting the primary means of contact of insects with the environment, being an essential organ for toxicity studies (Landim, 2009). In S. bipunctata bees orally contaminated with the fungicide Locker, the midgut showed morphological changes after exposure to the agrochemical in the three experimental periods.

The peritrophic membrane is a thin membrane-like structure that exists in the midgut lumen, wrapping food materials, separating it from the epithelial cells that constitute its wall, protecting the ventricle cells from friction and possible damage caused by the food not was digested, being present in insects that feed on solids (Landim, 2009).

Besides the excretory function, the digestive cells produce digestive enzymes and absorb the products of digestion (Landim, 2009). The degradation of digestive cells, their elimination in the lumen and the loosening of the longitudinal musculature, offered evidence of the degenerative effects of the fungicide used in this study.

Due to the large number of products containing strobilurin as an active ingredient, the risk for bees to be exposed becomes more frequent. For eusocial bees, it is important to understand the possible sublethal effects caused by fungicides throughout its life, since workers may present a detoxifying response, through enzymes such as glutathione S-transferase (GST), varying according to age (Diao, et al., 2005; Vannette et al., 2015).

The degenerative effects of compounds containing strobilurin have been investigated. Batista et al. (2020) analyzed the effects of strobilurin on A. mellifera midgut and observed morphological changes and cell death after being exposed to the fungicide for 24 to $96 \mathrm{~h}$. Although in this study, the data showed evidence of intestinal epithelial renewal in response to cytotoxic effects, this organ may have its nutrient absorption compromised in the long term, which can lead to malnutrition and affect individual performance, affecting the entire colony.

Domingues et al. (2020) compared the effects of pyraclostrobin residual concentrations in young and adult $A$. mellifera, evaluating histopathological and histochemical changes in the midgut of bees orally exposed to different sublethal concentrations of strobilurin. The results indicated that after five days of exposure, the fungicide induced sublethal effects in the midgut of adult workers. Carneiro et al. (2020) also evaluated the cytotoxic effects of oral contamination of A. mellifera with the fungicide iprodione and observed the impairment of the cells of the midgut that showed signs of apoptosis.

Thus, the action of agrochemicals on bees is adverse and may reflect on various aspects. Some responses occur through physiological and morphological changes, such as changes in muscles, epithelium and peritrophic membrane, which results in harmful behavior, impairing foraging and compromising colony survival (Roat et al., 2013). Besides, continuous exposure to sublethal doses of agrochemicals may prejudice the organs used during the metabolism of the pesticide (Catae et al., 2014, Oliveira et al., 2014, Diniz et al., 2020).

\section{Conclusion}

The ingestion of Locker by the bees used in this study can cause moderate mortality and alter morphophysiological processes necessary for their survival. Therefore, this agrochemical is considered dangerous for S. bipunctata workers health. Also, there is a lack in the literature regarding the effects of fungicides on stingless bees, making further studies on the lethal and sublethal effects of these chemicals necessary, to guarantee their preservation.

Thus, the following analyzes are suggested, gene expression to verify which genes are involved in the detoxification response and terminal dUTP nick-end labeling (TUNEL) analysis, characterized by apoptosis in the bees' midgut, to check for 
possible DNA fragmentation.

\section{References}

Adapar - Agência de Defesa Agropecuária do Paraná. http://www.adapar.pr.gov.br/.

Arena, M., \& Sgolastra, F. (2014). A meta-analysis comparing the sensitivity of bees to pesticides. Ecotoxicology, 23 (3), 324-334. 10.1007 / s10646-014$1190-1$

Barbosa, D. B., Crupinski, E. F., Silveira, R. N., \& Limberger, D. C. H. (2017). As abelhas e seu serviço ecossistêmico de polinização. Revista Eletrônica Científica da UERGS, 3 (4), 694-703. 10.21674/2448-0479.34.694-703

Bartlett, D. W., Clough, J. M., Godwin, J. R., Hall, A. A., Hamer, M., \& Parr-Dobrzanski, B. (2002). The strobilurin fungicides. Pest Management Science, 58 (7), 649-662. 10.1002 / ps.520

Batista, A. C., Domingues, C. E. C., Costa, M. J., \& Silva-Zacarin, E. C. M. (2020). Is a strobilurin fungicide capable of inducing histopathological effects on the midgut and Malpighian tubules of honey bees? Journal of Apicultural Research, (59) 5, 1-10. 10.1080/00218839.2020.1724678

Camargo, J. M. F., \& Pedro, S. R. M. (2013). Meliponini Lepeletier, 1836. In: Moure, J. S. \& Urban, D. eds. Melo GAR (Orgs) Catalogue of Bees (Hymenoptera, Apoidea) in the Neotropical Region. Curitiba, Brazil: UFPR; Online Version. http://www.moure.cria.org.br/catalogue.

Campbell, J. B., Nath, R., Gadau, J., Fox, T., Degrandi-Hoffman, G., \& Harrison, J. F. (2016). The fungicide Pristine ${ }^{\circledR}$ inhibits mitochondrial function in vitro but not flight metabolic rates in honey bees. Journal of Insect Physiology, 86 (3), 11-16. 10.1016 / j.jinsphys.2015.12.003

Carneiro, L. S., Martínez, L. C., Gonçalves, W. G., Santana, L. M., \& Serrão, J. E. (2020). The fungicide iprodione affects midgut cells of non-target honey bee Apis mellifera workers. Ecotoxicology and Environmental Safety, 189 (11), 1-7. 10.1016/j.ecoenv.2019.109991

Catae, A. F., Roat, T. C., Oliveira, R. A., Nocelli, R. C. F., \& Malaspina, O. (2014). Cytotoxic effects of thiamethoxam in the midgut and malpighian tubules of Africanized Apis mellifera (Hymenoptera: Apidae). Microscopy Research \& Technique, 77 (4), 274-281. 10.1002/jemt.22339

Coutinho, C. F. B., Galli, A., Mazo, L. H., \& Machado, S. A. S. (2006). Carbendazim e o meio ambiente: degradação e toxidez. Revista de Ecotoxicologia e Meio Ambiente, 16 (12), 63-70. 10.5380/pes.v16i0.7480

Diao, Q., Yuan, K., Liang, P., \& Gao, X. (2005). Tissue distribution and properties of glutathione S-transferases in Apis cerana cerana Fabricius and Apis mellifera ligustica Spinola. Journal of Apicultural Research, (45) 3, 145-152. 10.1080/00218839.2006.11101333

Diniz, T. O., Pereira, N. C., Silva, B. G., Pizzaia, W. C. S., Oliveira, F. G. M., Sinópolis-Gigliolli, A. A., \& Ruvolo-Takasusuki, M. C. C. (2020). Toxicity and effects of combined agrochemical in Scaptotrigona bipunctata bees. Scientific Electronic Archives, 13 (12), 41-53. 10.36560/131220201258

Diniz, T. O., Pereira, N. C., Pizzaia, W. C. S., Sinópolis-Gigliolli, A. A., Silva, B.G., Borges, Y. M., Guedes, T. A., \& Ruvolo-Takasusuki, M. C. C. (2020). Toxicity and genetic analysis of bees Scaptotrigona bipunctata after contamination with insecticide acephate. Scientific Electronic Archives, 13 (8), 8-17. $10.36560 / 13820201157$

Domingues, C. E. C., Inoue, L. V. B., Silva-Zacarin, E. C. M., \& Malaspina, O. (2020). Foragers of Africanized honeybee are more sensitive to fungicide pyraclostrobin than newly emerged bees. Environmental Pollution, 266 (2), 1-12. 10.1016/j.envpol.2020.115267

Freitas, B. M., \& Pinheiro, J. N. (2010). Efeitos sub-letais dos pesticidas agrícolas e seus impactos no manejo de polinizadores dos agroecossistemas brasileiros. Oecologia Australis, 14 (1), 282-298. 10.4257 / oeco.2010.1401.17

International Programme on Chemical Safety. Carbendazim. <http://www.inchem.org/documents/icsc/icsc/eics1277.htm>

Imperatriz-Fonseca, V. L. (2004). Serviços aos ecossistemas, com ênfase nos polinizadores e polinização. <http://files.cesaiifce.webnode.com.br/200000020bd221be1bb/Servi\%C3\%A7os\%20aos\%20ecossistemas, \%20com\%20\%C3\%AAnfase\%20nos\%20polinizad ores\%20e\%20poliniza\%C3\%A7\%C3\%A3o.pdf>.

Landim, C. C. (2009). Abelhas: morfologia e função de sistemas: UNESP.

Malaspina, O., \& Silva-Zacarin, E. C. M. (2006). Cell markers for ecotoxicological studies in target organs of bees. Brazilian Journal of Morphological Sciences, 23 (3), 303-309. http://www.jms.periodikos.com.br/article/587cb4627f8c9d0d058b463d

Nicodemo, D., Mingatto, F. E., Carvalho, A., Bizerra, P. F. V., Tavares, M. A., Balieira, K. V. B., \& Bellini, W. C. (2018). Pyraclostrobin impairs energetic mitochondrial metabolism and productive performance of silkworm (Lepidoptera: bombycidae) caterpillars. Journal of Economic Entomology, 111 (3), 1369 1375. 10.1093 / jee / toy060

Oliveira, R. A., Roat, T. C., Carvalho, S. M., \& Malaspina, O. (2014). Side-effects of thiamethoxam on the brain and midgut of the africanized honeybee Apis mellifera (Hymenopptera: Apidae). Environmental Toxicology, 29 (10), 1122-1133. 10.1002 / tox.21842

R Core Team. (2020). R: a language and environment for statistical computing. Vienna, AT: R Foundation for Statistical Computing.

Richardson, R. J. (1999). Pesquisa social: métodos e técnicas: Atlas.

Roat, T. C., Carvalho, S. M., Nocelli, R. C. F., Silva-Zacarin, E. C. M., Oalma, M. S., \& Malaspina, O. (2013). Effects of sublethal dose of fipronil on neuron metabolic activity of Africanized honeybees. Archives of Environmental Contamination and Toxicology, 64 (3), 456-466. 10.1007/s00244-012-9849-1 
Research, Society and Development, v. 10, n. 1, e53710112029, 2021

(CC BY 4.0) | ISSN 2525-3409 | DOI: http://dx.doi.org/10.33448/rsd-v10i1.12029

Rodenhiser, D., \& Mann, M. (2006). Epigenetics and human disease: translating basic biology into clinical applications. Canadian Medical Association Journal, 174 (3), 341-348. 10.1503 / cmaj.050774

Rossi, C. A., Roat, T. C., Tavares, D. A., Cintra-Socolowski, P., \& Malaspina, O. (2013). Effects of sublethal doses of imidacloprid in Malpighian tubules of africanized Apis mellifera (Hymenoptera, Apidae). Microscopy Research and Technique, 76 (5), 552-558. 10.1002 / jemt.22199

Sanchez-Bayo, F., \& Goka, K. (2014). Pesticide residues and bees - A risk assessment. PLoS ONE, 9 (4), e94482. 10.1371/journal.pone.0094482

Santos, S. A., Fermino, F., Moreira, B. M. T., Araújo, K. F., Falco, J. R. P., \& Ruvolo-Takasusuki, M. C. C. (2014). Critical electrolyte concentration of silk gland chromatin of the sugarcane borer Diatraea saccharalis, induced using agrochemicals. Genetics and Molecular Research, 13 (3), $7958-7964$. 10.4238/2014.September.29.9

Sidrim, J. J. C., \& Rocha, M. F. G. (2012). Micologia médica à luz dos autores contemporâneos: Guanabara Koogan.

Sueth-Santiago, V., Franklim, T. N., Lopes, N. D., \& Lima, M. E. F. (2015). CYP51: Uma Boa Ideia? Revista Virtual de Química, 7 (2), $539-575$. $10.5935 / 1984-6835.20150024$

Tavares, D. A., Roat, T. C., Carvalho, S. M., Silva-Zacarin, E. C. M., \& Malaspina, O. (2015). In vitro effects of thiamethoxam on larvae of Africanized honey bee Apis mellifera (Hymenoptera: Apidae). Chemosphere, 135 (5), 370-378. 10.1016/j.chemosphere.2015.04.090

Thany, S. H., Bourdin, C. M., Graton, J., Laurent, A. D., Mathé-Allainmat, M., Lebreton, J., \& Questel, J. Y. L. (2015). Similar Comparative Low and High Doses of Deltamethrin and Acetamiprid Differently Impair the Retrieval of the Proboscis Extension Reflex in the Forager Honey Bee (Apis mellifera). Insects, 6 (4), 805-814. 10.3390/insects6040805

Tison, L., Hahn, M. L., Holtz, S., Robner, A., Greggers, U., Bischoff, G., \& Menzel, R. (2016). Honey Bees' Behavior Is Impaired by Chronic Exposure to the Neonicotinoid Thiacloprid in the Field. Environmental Science \& Technology, 50 (13), 7218-7227. 10.1021/acs.est.6b02658

Vannette, R. L., Mohamed, A., \& Johnson, B. R. (2015). Forager bees (Apis mellifera) highly express immune and detoxification genes in tissues associated with nectar processing. Scientific Reports, 5 (1), 1-9. 10.1038/srep16224

Vidal, B. C. (1987). Métodos em biologia celular. In: Vidal, B. C., \& Mello, M. L. S. eds. Biologia Celular: Atheneu.

Vidal, B. C., \& Mello, M. L. S. (1989). Critical electrolyte concentration of DNA and nucleoprotein complexes in vitro. Acta Histochemica et Cytochemica, 22 (4), 471-478. 10.1267/ahc.22.471

Zauza, E. A. V., Couto, M. M. F., Maffia, L. A., \& Alfenas, A. C. (2008). Eficiência de fungicidas sistêmicos no controle da ferrugem do Eucalyptus. Revista Árvore, 32 (5), 829-835. 10.1590/S0100-67622008000500007 